УДК 621.391 .272

\title{
К ВЫБОРУ ВИДА МОДУЛЯЦИИ В АКУСТООПТИЧЕСКОЙ ЛИНИИ ЗАДЕРЖКИ С ПРЯМЫМ ДЕТЕКТИРОВАНИЕМ
}

\author{
ГАСАНОВ А. P., ГАСАНОВ Р. А.
}

Национальная академия авиаџии Азербайджана, Азербайджанская Республика, Баку, AZ1045, пос. Бина, 25-й км

\begin{abstract}
Аннотация. Приведена физико-математическая интерпретация последовательности формирования отклика на выходе акустооптической линии задержки с прямым детектированием при различных формах подключаемого к клеммам электроакустического преобразователя высокочастотного колебания. Показано, что для выбранной конструкции интенсивность света, падающего на фоточувствительную поверхность фотодетектора, изменяется только в случае изменения акустической мощности в фотоупругой среде. Это исключает возможность использования угловой модуляции для переноса спектра видеосигнала в область рабочих частот акустооптического модулятора в акустооптической линии задержки с прямым детектированием. Для обеспечения такой возможности предлагается установить на пути распространения отклоненного света опорный транспарант, который преобразует изменения угла дифракции в соответствующие изменения интенсивности света, падающего на фоточувствительную поверхность фотодетектора. Предложенная конструкция исследована для квадратной и круглой апертуры светового пучка. Установлено, что наилучшие результаты обеспечиваются при световом пучке с квадратной апертурой и с равномерным распределением плотности потока мощности в ней. Приведены основные результаты экспериментальных исследований, которые подтверждают эффективность действия предложенной конструкции
\end{abstract}

Ключевые слова: акустооптический модулятор; лазер, световой пучок; модуляция; акустооптическая линия задержки; частотная модуляция; упругая волна; дифракция Брэгга; угол Брэгга; угол дифракции; девиация частоты; время задержки; видеоимпульс; фотоприемник

\section{1. ОБЩИЕ СВЕДЕНИЯ, ПОСТАНОВКА ЗАДАЧИ И ЕЕ СОСТОЯНИЕ}

Свойства акустооптического эффекта используются для построения многочисленных устройств и систем обработки электрических сигналов [1]. К таким устройствам относятся акустооптические линии задержки (АОЛЗ) [2], которые обеспечивают плавноуправляемую задержку широкополосных электрических сигналов и могут быть использованы для коррекции временных искажений сигналов [3], формирования видео- и радиоимпульсов с параметрами, отличающимися от исходных значений [4], и т.д.
Различают АОЛЗ с прямым детектированием и гетеродинного типа [4]. АОЛЗ первого типа используются для обработки видеосигналов, а АОЛЗ второго типа — для обработки радиосигналов.

Согласно структурно-электрической схеме АОЛЗ с прямым детектированием (рис. 1), обрабатываемый видеосигнал $u_{\text {вх }}(t)$ модулирует колебание генератора высокой частоты (ГВЧ). Модулированное высокочастотное колебание с несущей частотой $\Omega$ подается на клеммы прикрепленного к торцу фотоупругой среды (ФУС) электроакустического преобразователя (ЭАП) длиной $L$ и шириной $H$. Отме- 